Article

\title{
Improving the Matrix-Assessment of Ecosystem Services Provision-The Case of Regional Land Use Planning under Climate Change in the Region of Halle, Germany
}

\author{
Lydia Gorn, Janina Kleemann * and Christine Fürst
}

Department of Sustainable Landscape Development, Institute for Geosciences and Geography, Martin-Luther-University Halle-Wittenberg, Von-Seckendorff-Platz 4, 06120 Halle (Saale), Germany; lydia.gorn@student.uni-halle.de (L.G.); christine.fuerst@geo.uni-halle.de (C.F.)

* Correspondence: janina.kleemann@geo.uni-halle.de; Tel.: +49-345-552-6028

Received: 8 May 2018; Accepted: 11 June 2018; Published: 13 June 2018

\begin{abstract}
Against the background of climate change, current and future provision of ecosystem services (ES) will also change. The recording of current provision potentials and its development in future is important for adapted regional planning. ES assessments are frequently carried out in the context of expert-based surveys, which have, however, revealed little information to date about uncertainties. We present a novel approach that combines the ES matrix assessment with the Delphi approach, confidence ratings, standardized confidence levels, and scenario assessment. First, the most important ES and their current and future provision potentials were identified by expert-based surveys in the study region, Halle (Saale) in Germany. Secondly, land use scenarios under climate change were developed that maintain the most important ES. The scenarios were assessed by the experts. Our study showed that the relevance of food as a provisioning ES, as well as spiritual values and recreational/landscape beauty as cultural ES, is high. A high level of acceptance was achieved by the afforestation scenario. Integration of the Delphi approach, confidence ratings, and confidence levels into the ES matrix assessment is an appropriate combination for estimating uncertainties in expert-based knowledge, thus contributing to the uncertainty assessment in regional planning.
\end{abstract}

Keywords: land use change; assessment; mixed-methods; expert-based; transdisciplinary; Halle (Saale), Germany

\section{Introduction}

Climate change is threatening ecosystems and their services [1-3] in addition to the exploitation of natural resources, destruction of habitats, pollution of the environment and soil degradation by human beings [4]. However, ecosystem services (ES) are of essential significance for human beings, since they assure human needs such as food and drinking water [4,5]. Provision of ecosystem services (ES) is endangered; about $60 \%$ of the ES investigated thus far have been degraded in the last 50 years, or have been used unsustainably [6], and further deterioration of many ES worldwide has been projected $[1,7]$.

According to the Common International Classification of Ecosystem Services, ES can be divided into the following categories: (a) provisioning services (e.g., timber, biomass); (b) regulation and maintenance (e.g., protection against floods and reduction of harmful substances); and (c) cultural services (e.g., recreation and landscape beauty, and spiritual values) [8]. Recording, analysis and assessment of ES and their provision under climate change is important to predict future changes in ES and to avoid a decline in the provision of ES [9]. In this case, adaptations in land use have to be undertaken. Regional planning plays an important role, since adaptive measures must be implemented 
at the regional and local levels [10]. However, the adaptive measures could raise the issue of so-called trade-offs, as the improvement of one ES could reduce the provision of another. [11].

Scenarios are used in regional planning to support decision-making [12,13]. Scenario design is a powerful tool to assess trade-offs between ES [14,15], to visualize development pathways and future options to identify contrasting trends [16], to understand impacts on ES [17], and to evaluate and compare scenarios [18] regarding (desirable) impacts of, e.g., land use and land cover changes, on ES [19]. However, scenario development and assessment as well as ES research in general is frequently confronted with uncertainties $[20,21]$ due to a high level of complexity, unknown functionalities, and unforeseeable dynamics in socio-ecological systems [22], as well as inconsistent data and data gaps. Therefore, qualitative methods such as expert-based surveys should be integrated. Popular techniques for ES assessments are expert-based estimations regarding the potential of ES provision through classes of land use and land use cover-so-called matrix models [23,24]. However, there also exist weaknesses in expert-based methods in general and matrix approaches in particular, namely the rather inferior methodological transparency, comparatively low replicability, uncertainties with regard to the quality of the results, as well as the scarcely available reporting of reliability [25]. Further development of the above-mentioned approaches and methods is essential for being able to make assertions about future potential provision of ES [10].

The objective of this study was to introduce an innovative assessment process for ES against the background of climate change, which combines qualitative, expert-based approaches of analysis regarding provision potentials for ES while informing on uncertainties of the qualitative assessment. The region Halle (Saale) in Germany was selected as the area of investigation since the region is exemplary for landscapes in Germany that are subject to a considerable transformation of land use and high demographic changes which effectuate a high level of uncertainty in the assessment of the ES provision potential. The region has presumably been impacted by climate change [26], whereby changes in the provision of ES are to be expected. In our knowledge, assessments of ES provision potential in connection with climate change were not yet conducted for the study area. The following research questions were tested with the new methodological approach:

- Which ES are considered relevant by experts in the study area?

- What is the potential for land use types to provide selected ES under current and future influences from climate change?

- Which land use scenarios arise from the most relevant ES for the region, and how acceptable are they for the experts?

The following hypotheses have been established:

- It is primarily the provisioning ES that are perceived as important, since other studies have already shown this tendency $[11,27,28]$.

- The potential to provide ES will change in the region due to climate change.

- A land use scenario that is concentrated on agricultural intensification will be less accepted than one that reflects an expansion of forest area.

\section{Materials and Methods}

\subsection{Improving Expert-Based Surveys by Using Combined Approaches}

Burkhard et al. (2009) [23] proposed a matrix for the qualitative assessment of provision potential of ES provided by different land use/cover types $[23,29,30]$. With those values acquired from the matrix, maps can be created showing the spatial provision potential of ES and used to support the decision-making process in landscape and regional planning [31]. In the case of data scarcity, experts can be consulted to estimate the potential ES provision through land use/land cover classes. With the designation "expert", we refer to a person to whom special knowledge is attributed based on experience, training and/or profession regarding a certain state of affairs [21,25]. 
However, the ES matrix assessment and expert-based approaches have weaknesses in, among other things, the assessment of uncertainties and the quality of data [25]. This paper introduces an approach which improves the matrix method and expert-based surveys by using the Delphi approach, confidence ratings, standardized confidence levels, scenario development and its assessment. In the following, the main approaches are described.

- Delphi approach: The basic idea behind the Delphi approach involves deploying expert opinions regarding problem solving while making use of anonymous feedback [32,33]. Anonymity affords the participants the opportunity to compare their opinions regarding a certain state of affairs and to make alterations, if necessary, without being influenced by the other participants. The expectation is that a structured and repetitive survey will improve robustness during the process [32,34].

- Confidence ratings: Consensus allows progress in complex situations, but does not necessarily guarantee a reliable result [25]. By means of a confidence rating, the level of confidence should be increased by asking about one's own certainty in reference to the object to be assessed [35].

- Standardized confidence levels: To deal with uncertainties, a well-known approach was selected for this paper-the standardized confidence level of the Intergovernmental Panel on Climate Change (IPCC, 2013) [36]—where statements regarding agreement are combined with scientific evidence (which also includes expert estimations) regarding confidence levels [37]. Jacobs et al. (2015) [25] proposed forming a level of confidence in a similar, standardized manner, which leads to an increase in confidence in the results.

- Scenario development and assessment in the matrix method: The results from matrix assessments are often expressed in the form of maps for the provision of ES [25]. In several studies, furthermore, the impact on ES provision potentials is illustrated in land use change scenarios [38]. This study has gone one step further by having scenarios of land use changes and their impacts upon regional ES assessed by experts to acquire feedback from daily practice.

\subsection{Area under Investigation}

The $3713 \mathrm{~km}^{2}$ investigated region lies in southern Saxony-Anhalt in Germany [39] (Figure 1). The region of Halle was used to illustrate the combined assessment approach, since fast access was guaranteed due to existing contacts with local experts.

The investigated region is predominantly agricultural land (76\%). Much less area is dedicated to forests $(7 \%)$ and settlement areas $(8 \%)$ [40,41]. Saxony-Anhalt has a low share of forest compared to other Federal States in Germany [42]. The majority of agricultural use consists of farmland use [43]. The climate in Saxony-Anhalt is characterized by dry summers and cold winters. The mean annual temperature is approximately $8.6^{\circ} \mathrm{C}$ and annual precipitation is about $550 \mathrm{~mm}$ [26].
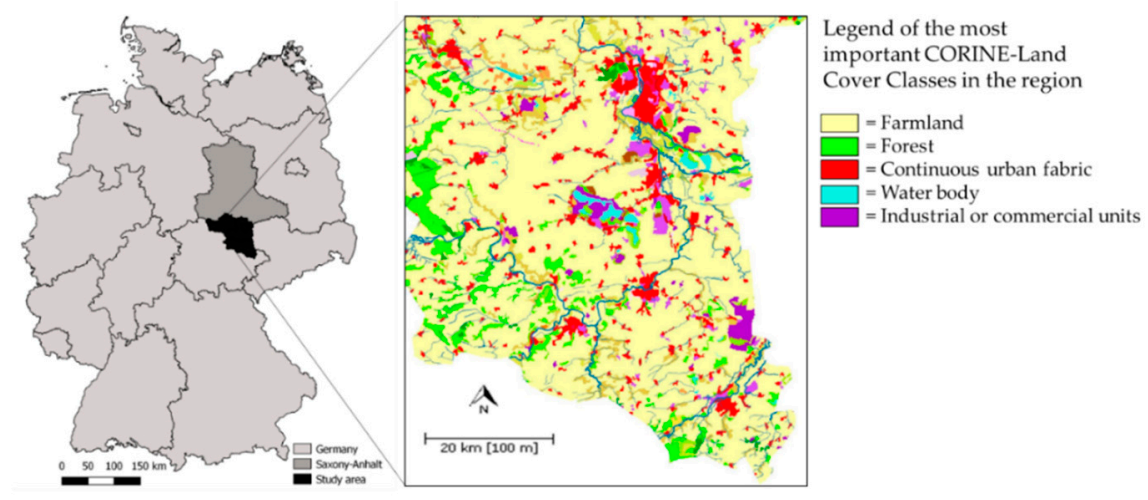

Figure 1. Location of the planning region Halle in Germany. Administrative borders to Germany. The study area (in black) lies in the Federal State of Saxony-Anhalt [44]. The planning region is shown on the right with a land cover map according to CORINE-Land Cover Classes (2006) [40]. 
Today, a few areas in the Federal State are already exhibiting a negative climatic water balance for the annual mean. Against the background of the IPCC scenarios [45], the study area will most likely be impacted, according to regional climate studies, by climate change involving the following points through to the end of this century [26]:

- Rise in temperature, primarily in summer and winter;

- Trend towards increased summer drought;

- Decrease in climatic water balance;

- Increase in extreme weather events; and

- A prolonged vegetation period.

As a result of the above-mentioned points, changes can emerge in the provision of ES such as food, water supply and wood production. For example, low increases in productivity are expected for forests depending on the growth habitat and range of species, in part with negative yield expectations [26]. In the land use modeling, these changes can be predicted. In addition, the scenario modeling enables documentation of the local acceptance of potential adaptations to climate change.

\subsection{Spatial Data}

Data of CORINE Land-Cover of 2006 (CLC-2006) were used as basis for the spatially-explicit modeling approach. The CLC-2006 data were based on satellite images from Landsat 7 and IRS-P6 LISS-III as well as SPOT-4 and SPOT-5 with $20-30 \mathrm{~m}$ resolution. These data were interpreted and converted into three hierarchy levels with 44 different land cover classes, of which 40 were relevant for the area under investigation. The CLC-2006 data were mapped on a scale of 1:100,000 with a minimum area size in the landscape polygons of 25 ha [40].

\subsection{Survey Groups}

Two types of experts were selected who differentiated in their knowledge regarding regional ES and planning: Expert type A had topic and context specific knowledge with practical experience in the regional planning and ES. Expert type B had theoretical knowledge of the spatial and environmental planning, the regional geography and ES. Expert type A was acquired through personal recommendations and by searching the websites for employees of regional enterprises and institutions that represent relevant subject areas for the regional planning. The identified individuals were contacted personally by telephone and/or email and asked to recommend further experts (snowball technique) [46]. The experts represented the subject areas forestry, water management, nature conservation, regional development and climate protection. Expert type B consisted of students from the University of Halle. The students represented the subject areas Geography, Management of Natural Resources and International Area Studies (see Table 1).

Table 1. Amount, type and professional background of the experts.

\begin{tabular}{|c|c|c|}
\hline Expert Type & Subject Area & Expertise \\
\hline $\mathrm{A}(n=8)$ & $\begin{array}{l}\text { Representatives from the regional } \\
\text { administration, forestry, } \\
\text { environmental protection, flood } \\
\text { protection and water management, } \\
\text { regional development }\end{array}$ & $\begin{array}{ll}\text { - } & \text { Preparation and execution of climate protection measures } \\
\text { - } & \text { Preparation of regional plans } \\
\text { - } & \text { Knowledge of regional forests } \\
\text { - } & \text { Knowledge of socio-ecological relationships } \\
\text { - } & \text { Knowledge of the regional water balance } \\
\text { - } & \text { Knowledge of the socio-political context } \\
\text { - } & \text { Knowledge of the ecosystem services concept } \\
\end{array}$ \\
\hline $\mathrm{B}(n=39)$ & $\begin{array}{c}\text { Students in Management of } \\
\text { Natural Resources and Geography, } \\
\text { and International Area Studies at } \\
\text { University of Halle }\end{array}$ & $\begin{array}{l}\text { - } \quad \text { Basic knowledge as well as advanced knowledge of spatial } \\
\text { and environmental planning } \\
\text { - } \quad \text { Knowledge of regional geography } \\
\text { - } \quad \text { Basic knowledge regarding the ecosystem services concept }\end{array}$ \\
\hline
\end{tabular}




\subsection{Application of the Combined Methods and Survey Process}

The following steps were carried out, each with its own surveys and objectives, which build on one another (see Figure 2):

Step 1: Delphi survey for the identification of regionally relevant ES (Section 2.5.1).

Step 2: Matrix assessment for an investigation of how the ES identified in Step 1 behave under the influence of climate change; executed as a Delphi survey and as a comparison for a one-time survey (Section 2.5.2).

Step 3: Scenario design based on results contained in Step 2 (Section 2.5.3).

Step 4: Scenario assessment by a one-time expert survey (Section 2.5.4).

All surveys were conducted as questionnaires and designed according to scientific guidelines [32,47]. The questionnaire was sent via email to expert type A. Regarding expert type $\mathrm{B}$, the questionnaire was completed directly on the campus of the University of Halle. Within expert type B, there were various survey groups: the first survey group that was re-surveyed in a second round (=Delphi group) and a control group that was surveyed once. It was determined beforehand that the Delphi survey should consist of two rounds to avoid a survey exhaustion and possible withdrawal of the experts [48]. The experts of type A were given between two and four weeks to answer the questionnaires.

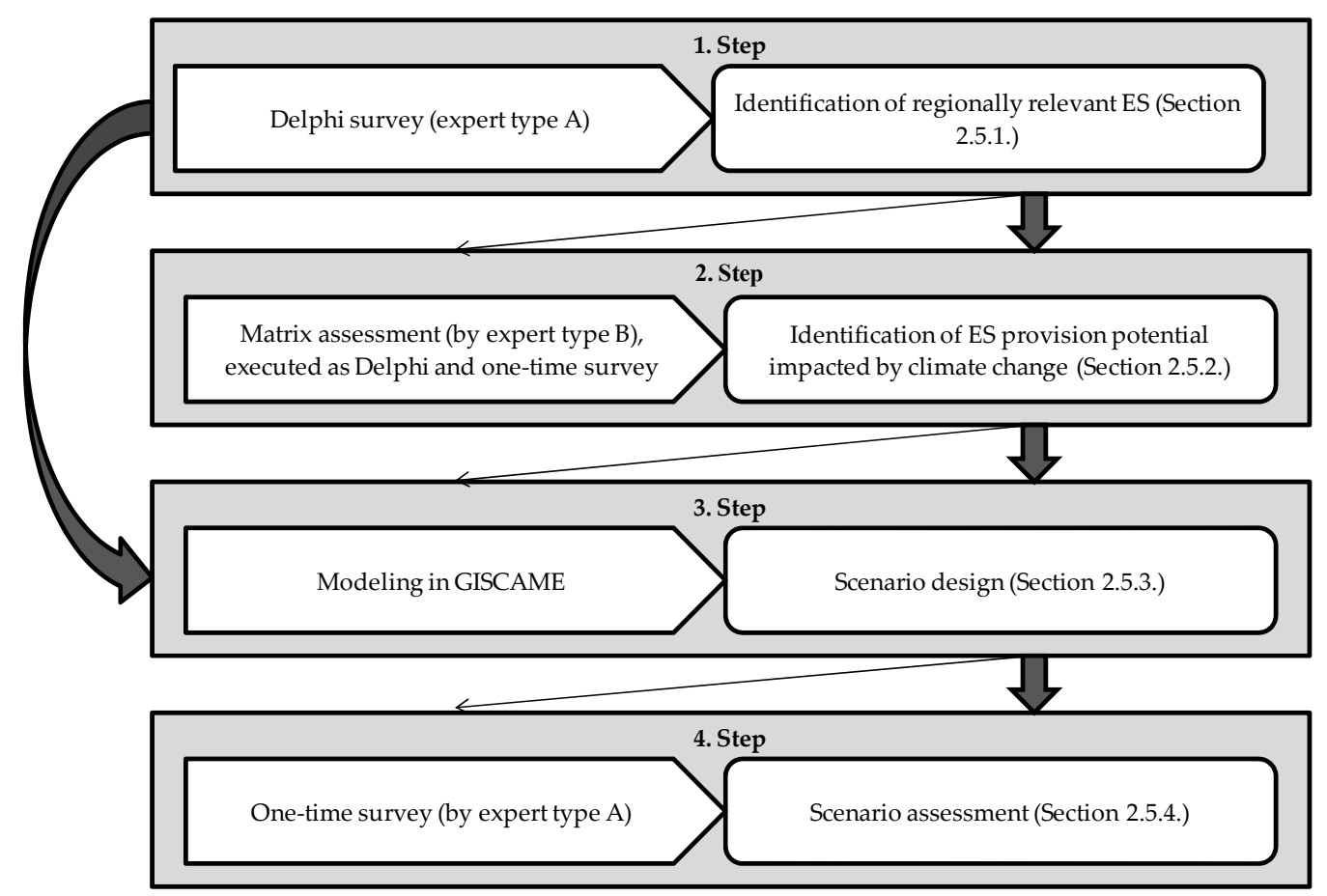

Figure 2. Representation of the process in four steps with respective methods and expected results. Step 3 was also based on Step 1. Objectives on the right and methods on the left. Expert type A = Representatives from the regional land use planning; Expert type B = Students from regional planning at the University of Halle; ES = Ecosystem Services.

\subsubsection{Step 1: Delphi Survey for the Identification of Regionally Relevant Ecosystem Services}

The Common International Classification of Ecosystem Services (CICES, 2013) [8] was selected as ES classification, since it is a scientifically accepted ES classification framework [49] (see Section 1). The participants were asked to rank the ES listed according to CICES in both Delphi rounds based on a Likert scale with regard to regional relevance of the ES from not relevant (0) to very relevant (5). The experts were furthermore asked to submit their confidence rating for each assessment, i.e., 
how confident they are in their assessment. The Likert scale spanned from very unconfident (1) to very confident (5). The same Likert scale was also used in the subsequent surveys to check the confidence ratings.

The results were evaluated based on absolute frequencies. For this purpose, the values in the Likert scale were divided into: $0-1=$ low relevance, $2-3=$ medium relevance, $4-5=$ high relevance. To increase the clarity of the evaluation, the results were weighted with factors and subjected to a ranking. Weighting the results is a conventional practice (see for example [50]). For this purpose, the generated categories were multiplied by the following factors: medium relevance times 1 , and high relevance times 2 (see Table 2). All ES that achieved a valued of 5 or less in round 1 of the Delphi approach were categorized as less relevant for the study area and excluded from further assessments. In round 2, the six ES with the highest values were identified as regionally relevant, serving thereby as the assessment basis for the matrices in Step 2 to keep the procedure clear.

Table 2. Classification of the Likert scale and weighting factor (own presentation).

\begin{tabular}{ccc}
\hline Likert-Scale & Category of ESS & Weighting \\
\hline 0 & Low Relevance & - \\
1 & Medium Relevance & $\begin{array}{c}\text { Category of the Likert scale } \\
\text { multiplied by } 1\end{array}$ \\
\hline 2 & High Relevance & $\begin{array}{c}\text { Category of the Likert scale } \\
\text { multiplied by } 2\end{array}$ \\
\hline 4 & & \\
\hline
\end{tabular}

2.5.2. Step 2: Matrix-Based Assessment for Identification of Ecosystem Services Impacted by Climate Change

In addition to competence and demographic enquiries, the matrix method formed the core of the questionnaire according to Burkhard et al. (2009) [23], whereby the y-axis of the matrix reflects the land use classes, and the $\mathrm{x}$-axis contains ES which are represented by the land cover class. The questionnaire contains two matrices. The first matrix is meant to be assessed under present climatic conditions in the study area. For the second matrix, the assessment is meant to be conducted regarding climate change for the region (see also Section 2.2): rising temperatures, increased risk of summer droughts, a decrease in the climatic water balance, an increase in extreme weather events and a prolonged vegetation period. On the Y-axis of the matrix, the regional CORINE Land Cover Classes (LCC) were located-for example agricultural land, mixed forests and the network of streets. The previously identified regionally relevant ES were located on the X-axis. The ES provision potential by the respective LCC was rated on a Likert scale from no potential (0) to high potential (5). The enquiry and scale for the confidence rating were integrated into the questionnaire.

The values acquired in the matrices were processed with Statistica (version 13.0, StatSoft). For the assessments of the provision potential of ES and assessments for the respective confidence rating, the means and respective standard deviations were calculated. Based on the obtained means and standard deviations, we classified the assessment scores into three levels: low, medium and high. To achieve a higher level of objectivity, the Likert scales were divided up into three sections of equal dimension. Different classifications of the values for the confidence rating and for the ES provision potential were generated due to the various levels in the scale. The classification for the standard deviation was the same as for the confidence rating and ES provision potential: 1.7 was considered to be a high standard deviation, 0.9-1.6 medium, and 0-0.8 low (see column and row headings in Table 3 for a more detailed overview of the classification of the means).

Modified confidence levels were developed for the means and standard deviations of the assessments of the ES provision potential and assessments for the confidence rating according to IPCC (see Table 3). The confidence levels of the 5th IPCC report comprise the quantity of scientific evidence 
(robust, medium and limited) and scientific agreement (high, medium, low). The combination of the evidence and agreement levels results in five confidence levels: very high, high, medium, low and very low [37]. For our study, we regarded the experts' estimations concerning the ES provision potentials as the evidence levels. The confidence rating was seen as agreement levels. With the aid of the confidence level, the assessments of the matrices were analyzed. The ES impacted by climate change were identified by the following criteria: (a) the ES must currently be provided to a high degree by the corresponding LCC (the mean of the ES provision potential $\geq 3.4$ ); (b) the respective confidence level must be high or very high; and (c) the mean of the current ES provision potential must change by at least 0.5 under climate change.

Table 3. Confidence level, modified according to Mastrandea et al. (2011) [37] and Jacobs et al. (2015) [25] for the matrix results. The confidence levels are composed of the assessments and the subsequent classification of the confidence ratings and the Ecosystem Services (ES) provision potential. The classifications have been shown here in the line and column headings in parentheses. $\mathrm{CR}=$ Confidence Rating; $\mathrm{M}=$ Mean; $\mathrm{SD}=$ Standard Deviation.

\begin{tabular}{cccc}
\hline Confidence Level & $\begin{array}{c}\text { Low ES Provision } \\
\text { Potential (M 0-1.3) }\end{array}$ & $\begin{array}{c}\text { Medium ES Provision } \\
\text { Potential (M 1.4-3.3) }\end{array}$ & $\begin{array}{c}\text { High ES Provision } \\
\text { Potential (M from 3.4) }\end{array}$ \\
\hline High CR (M 3.8-5.0) & Medium & High & Very High \\
Medium CR (M 2.4-3.7) & Low & Medium & High \\
Low CR (M 1-2.3) & Very Low & Low & Medium \\
\hline
\end{tabular}

\subsubsection{Step 3: Scenario Design}

Based on the results from Step 2, scenarios were prepared in the planning software GISCAME (PiSolution, Markkleeberg, Germany [41]). GISCAME is a web-based modeling platform that can be used to simulate alternative land-use scenarios (through changes in LCC). Based on these scenarios, benefits or risks for regionally important ES can be assessed. It supports the visualization and evaluation of the effects of changes in land use patterns [50]. GISCAME consists of a combination of cellular automata with GIS functions and a multi-criteria assessment. The spatial layout is based on CORINE land cover data [12,50]. GISCAME generates an expert-supported estimation of the provision of ES from the respective LCC in the matrix format (please see Fürst et al. 2010a,b [12,50] for more information on GISCAME).

Design of the scenarios was based on the regionally relevant ES identified in Step 1 and the changes in ES due to climate change ascertained in Step 2. The ES were processed through the scenarios if they fulfilled the following criteria: (a) the ES must currently be potentially provided to a high degree; (b) there is a negative change in the ES provision potential due to climate change; and (c) the confidence level of the current ES provision potential is at least at a high level. The latter condition is listed to increase the confidence in the results, since GISCAME takes no variances into account. The normalized means of the Delphi group of the expert type B were entered into GISCAME due to their higher confidence level. To simplify the later assessment, two high-contrast scenarios for the most important ES were designed. Furthermore, a compromise scenario was developed where a combination of the most important ES was provided to take trade-offs between the ES into account. According to the German Federal Nature Conservation Act, a threat to the ES must be prevented and the functionality of the ecosystem must be secured [51]. Therefore, scenarios were designed that reduced the negative effect of climate change on ES through the expansion of the corresponding LCC.

\subsubsection{Step 4: Scenario Assessment}

Scenario assessments are often used in combination with participatory approaches [52,53]. For example, experts are contacted to gather feedback on the likelihood of an event [19]. We used an approach where scenarios are assessed according to the level of acceptance for the respective scenario. We differentiate two levels here: "acceptable" and "recommendable". "Acceptable" refers to a minimal 
level of acceptance. With "recommendable", the expert considers the scenario to be appropriate, which is therefore superior to "acceptable." The experts were asked: (a) how recommendable; and (b) how acceptable they consider the scenario to be. They were also asked to express the degree of agreement in this regard on a Likert scale from "do not agree at all" (1) to "agree absolutely" (5). The results from the previous surveys were presented to the experts to better understand the scenario development. Moreover, the changes undertaken in the scenarios were explained and shown as a map for better visualization. For evaluation, the Likert scale was summarized as follows: "agreement", "partial agreement" and "no agreement". The assessments were evaluated based on the absolute frequency of the agreement levels.

\section{Results}

\subsection{Regionally Relevant Ecosystem Services}

We have identified six ES that received the highest values and that were considered as regionally relevant. According to the assessment of the experts (type A), the following cultural, regulating and provisioning ES are regionally relevant in the study area: food production, biomass for energy, reduction of harmful substances, protection against floods, spiritual values and recreation/landscape beauty. Least relevant were the regulation of the global climate, regulation of the local/regional climate, biomass for further treatment and erosion control. The confidence ratings were predominantly high in the Delphi survey, which means that the experts were confident in the correctness of their statements.

\subsection{Expert Opinions Regarding Changes in Ecosystem Services Due to Climate Change}

The regionally relevant ES (identified in Section 3.1) were assessed by expert type B regarding their provision potential through CORINE-LCC. All of the survey groups estimated with higher uncertainties the ES provision potential of near-natural LCC with marginal areas (e.g., forest-shrub landscape, parcel structure) as low to medium provision potential. With high confidence, the ES are not provided by infrastructures. Group 1and the control group of expert type B assessed the provision potential and the confidence level of the regulating ES as low to medium (Table 5 and Table A1). In the Delphi group, the confidence was higher that the regulating ES are currently and under climate change not provided. Group 1 and the control group estimated the provision potential of agricultural LCC for energy generation from biomass higher, while the confidence levels were low to medium. In the Delphi group, the provision potential for energy generation from biomass was estimated as high for arable land with high confidence. Under climate change, the provision potential does not change for energy generation from biomass with high confidence.

The current and future provision potential of the regulating ES and biomass for energy were not analyzed further due to rather low provision potentials and rather low confidence levels. High provision potentials were regarded by all survey groups for food, recreation/landscape beauty and spiritual values. These ES decreased in the context of climate change (Tables 4 and 5). The assessments of the Delphi group were an exception. They assessed the provision potential of the cultural ES under climate change as being constant (Table 4). The confidence levels for cultural ES were medium to very high, while those of the Delphi group were high to very high.

Due to the high provision potentials and high confidence in the assessment by the experts, food, recreation/landscape beauty and spiritual value were identified as the most important ES in the region. Forest LCC were related to cultural ES potentials, while agricultural LCC were considered for food provision. The most important results are presented in Tables 4 and 5 and Table A1. 
Table 4. Assessment for food provision, recreation/landscape beauty and spiritual values by the Delphi group for forest and agricultural land cover classes. ES = Ecosystem service.

\begin{tabular}{|c|c|c|c|c|c|}
\hline ES & $\begin{array}{l}\text { Land Cover } \\
\text { Class }\end{array}$ & $\begin{array}{l}\text { Land Cover } \\
\text { Subclass }\end{array}$ & $\begin{array}{c}\text { Current Provision } \\
\text { Potential of ES } \\
\text { Color }=\text { Confidence } \\
\text { Level, } \\
\text { Value }=\text { Mean }\end{array}$ & $\begin{array}{c}\text { Future Provision } \\
\text { Potential of ES } \\
\text { Color }=\text { Confidence } \\
\text { Level, } \\
\text { Value }=\text { Mean }\end{array}$ & $\begin{array}{c}\text { Changes in ES } \\
\text { Provision by } \\
\text { Climate } \\
\text { Change }\end{array}$ \\
\hline \multirow{7}{*}{$\begin{array}{l}\text { Food } \\
\text { provision }\end{array}$} & \multirow{3}{*}{ Forest area } & Mixed forest & 1.67 & 1.92 & - \\
\hline & & Coniferous forest & 1.17 & 1.17 & - \\
\hline & & Broad-leaved forest & 2 & 2.42 & - \\
\hline & \multirow{4}{*}{$\begin{array}{l}\text { Semi-natural and } \\
\text { agricultural area }\end{array}$} & Agriculture & 4.92 & 4.42 & $\searrow$ \\
\hline & & $\begin{array}{l}\text { Fruit trees and } \\
\text { berries }\end{array}$ & 4.5 & 3.75 & $\searrow$ \\
\hline & & Vineyards & 3.33 & 2.92 & $\rightarrow$ \\
\hline & & Arable land & 5 & 4.5 & $\searrow$ \\
\hline \multirow{7}{*}{$\begin{array}{l}\text { Spiritual } \\
\text { values }\end{array}$} & \multirow{3}{*}{ Forest area } & Mixed forest & 4 & 4.25 & $\rightarrow$ \\
\hline & & Coniferous forest & 3.67 & 3.92 & $\rightarrow$ \\
\hline & & Broad-leaved forest & 3.75 & 3.83 & $\rightarrow$ \\
\hline & \multirow{4}{*}{$\begin{array}{l}\text { Semi-natural and } \\
\text { agricultural area }\end{array}$} & Agriculture & 1.58 & 1.67 & - \\
\hline & & $\begin{array}{l}\text { Fruit trees and } \\
\text { berries }\end{array}$ & 2.42 & 2.67 & - \\
\hline & & Vineyards & 2.67 & 2.33 & - \\
\hline & & Arable land & 1.58 & 1.08 & - \\
\hline \multirow{7}{*}{$\begin{array}{l}\text { Recreation/ } \\
\text { landscape } \\
\text { beauty }\end{array}$} & \multirow{3}{*}{ Forest area } & Mixed forest & 4.5 & 4.42 & $\rightarrow$ \\
\hline & & Coniferous forest & 4.33 & 4.17 & $\rightarrow$ \\
\hline & & Broad-leaved forest & 4.5 & 4.25 & $\rightarrow$ \\
\hline & \multirow{4}{*}{$\begin{array}{l}\text { Semi-natural and } \\
\text { agricultural area }\end{array}$} & Agriculture & 1.75 & 1.92 & - \\
\hline & & $\begin{array}{l}\text { Fruit trees and } \\
\text { berries }\end{array}$ & 2,83 & 2.92 & - \\
\hline & & Vineyards & 3 & $\begin{array}{l}2.92 \\
192\end{array}$ & \\
\hline & & Arable land & 1.58 & 1.92 & - \\
\hline \multicolumn{6}{|c|}{$\begin{array}{l}\text { Legend: } \square \\
\square=\text { Low col } \\
\text { provision of thi } \\
\text { this ESS does nn } \\
\text { least } 0.5) ;-=\text { Th } \\
\text { Section } 2.5 .2) .\end{array}$} \\
\hline ES & $\begin{array}{l}\text { Land Cover } \\
\quad \text { Class }\end{array}$ & $\begin{array}{l}\text { Land Cover } \\
\text { Subclass }\end{array}$ & $\begin{array}{c}\text { Current Provision } \\
\text { Potential of ES } \\
\text { Color }=\text { Confidence } \\
\text { Level, } \\
\text { Value }=\text { Mean }\end{array}$ & $\begin{array}{c}\text { Future Provision } \\
\text { Potential of ES } \\
\text { Color }=\text { Confidence } \\
\text { Level, } \\
\text { Value }=\text { Mean }\end{array}$ & $\begin{array}{c}\text { Changes in ES } \\
\text { Provision by } \\
\text { Climate } \\
\text { Change }\end{array}$ \\
\hline \multirow{7}{*}{$\begin{array}{c}\text { Food } \\
\text { provision }\end{array}$} & \multirow{3}{*}{ Forest area } & Mixed forest & 1.54 & 1.92 & - \\
\hline & & Coniferous forest & 1.38 & 1.77 & - \\
\hline & & Broad-leaved forest & 1.69 & 2.15 & - \\
\hline & \multirow{4}{*}{$\begin{array}{l}\text { Semi-natural and } \\
\text { agricultural area }\end{array}$} & Agriculture & 4.62 & 4 & $\searrow$ \\
\hline & & $\begin{array}{l}\text { Fruit trees and } \\
\text { berries }\end{array}$ & 4.54 & 3.85 & - \\
\hline & & Vineyards & 4.15 & 3.69 & $\rightarrow$ \\
\hline & & Arable land & 4.69 & 4.15 & $\searrow$ \\
\hline \multirow{7}{*}{$\begin{array}{l}\text { Spiritual } \\
\text { values }\end{array}$} & \multirow{3}{*}{ Forest area } & Mixed forest & 4.38 & 3.62 & $\searrow$ \\
\hline & & Coniferous forest & 4.15 & 3.31 & $\searrow$ \\
\hline & & Broad-leaved forest & 4.31 & 3.77 & $\searrow$ \\
\hline & \multirow{4}{*}{$\begin{array}{l}\text { Semi-natural and } \\
\text { agricultural area }\end{array}$} & Agriculture & 1.85 & 2.08 & - \\
\hline & & $\begin{array}{l}\text { Fruit trees and } \\
\text { berries }\end{array}$ & 2.85 & 3.15 & - \\
\hline & & Vineyards & 3.23 & 3.69 & - \\
\hline & & Arable land & 1.54 & 1.54 & - \\
\hline
\end{tabular}


Table 5. Cont.

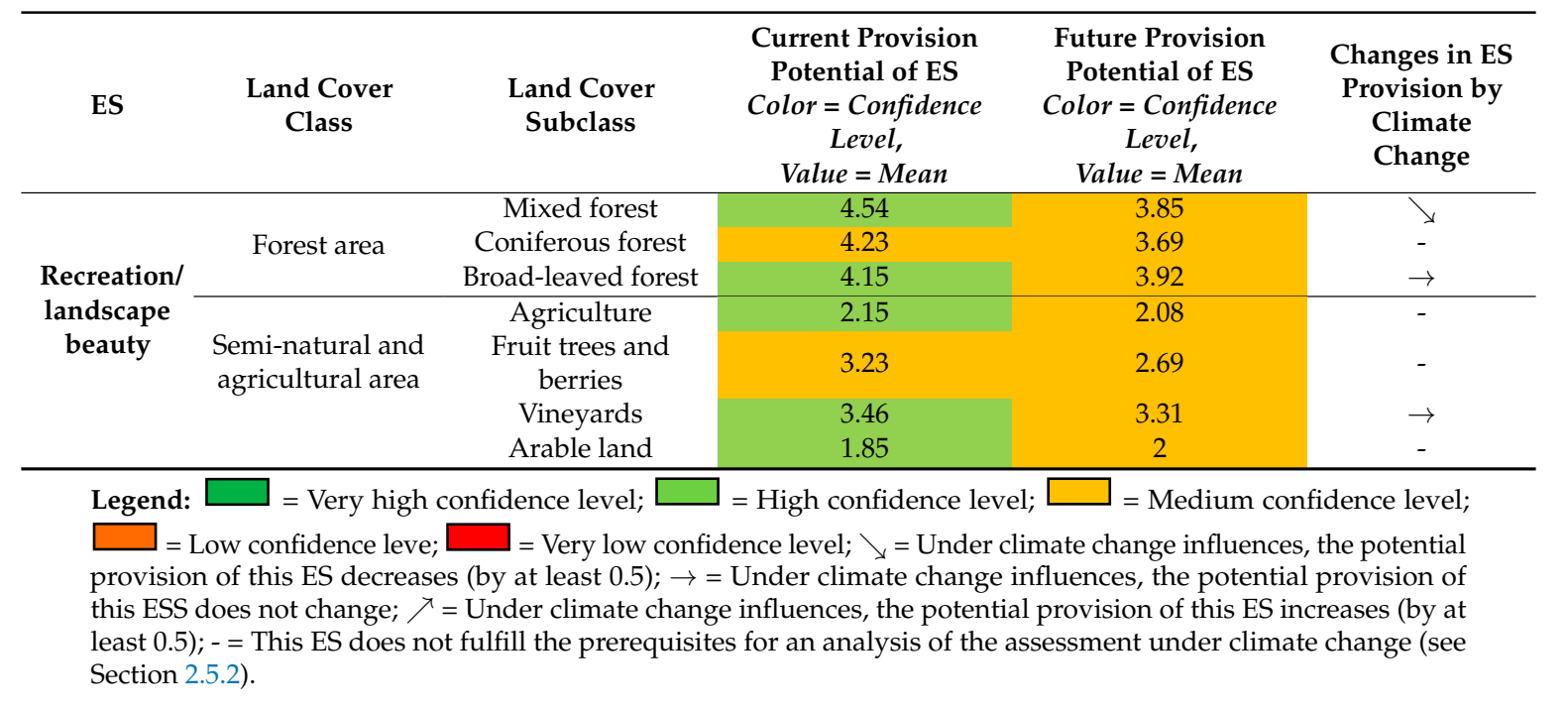

\subsection{Scenarios}

In Step 2, the connection between food provision and arable land as well as the connection between recreation/landscape beauty, spiritual values and forest were identified. Therefore, scenarios were designed that moderate the negative effects of climate change upon the selected ES due to change in land cover. This includes: (a) an intensification scenario; (b) an afforestation scenario; and (c) a scenario in which a compromise between the three most important ES was considered. In the intensification scenario, arable land was expanded by about $8 \%$ at the expense of semi-natural, extensive areas, to minimize the loss of potential provision of food. In the afforestation scenario, the forest area was expanded by about $5 \%$, whereby individual forest sections were also connected. The provision potential was improved hereby for recreation/landscape beauty and spiritual values. In the afforestation scenario, the food production decreased through the decrease in agricultural LCC; this leads to a trade-off between agricultural LCC and forest LCC and the potentially provided ES. In the compromise scenario, intensification and afforestation were combined. Arable land and mixed forest were expanded by about $5 \%$. Especially extensive and marginal areas were considered as potential convertible areas. Forest areas are preserved by the Federal Forest Act [54] and the transformation of settlement areas is not realistic.

\subsection{Assessment of the Scenarios}

In the scenarios, the modifications in land use were mainly located in the western and southern parts of the planning region, where mainly extensive agricultural area is located. In the afforestation scenario, small forests were connected in these areas. Intensification was viewed by the experts as a neither acceptable nor recommendable scenario (scenario A in Table 6). In contrast, afforestation was estimated to be an acceptable and recommendable scenario (scenario B in Table 6) by most of the experts. One expert considered the afforestation scenario to be neither acceptable nor recommendable. Experts rather disagreed and were uncertain about the compromise scenario (Scenario C in Table 6). Three of five experts considered the compromise scenario as recommendable. Two experts regarded it as acceptable. 
Table 6. Spatial layout of the three selected land use scenarios. Scenario A: Intensification of agriculture; Scenario B: Afforestation; Scenario C: Compromise between A and B. Moreover, the diagram reflects the level of acceptance for the scenarios by the experts.

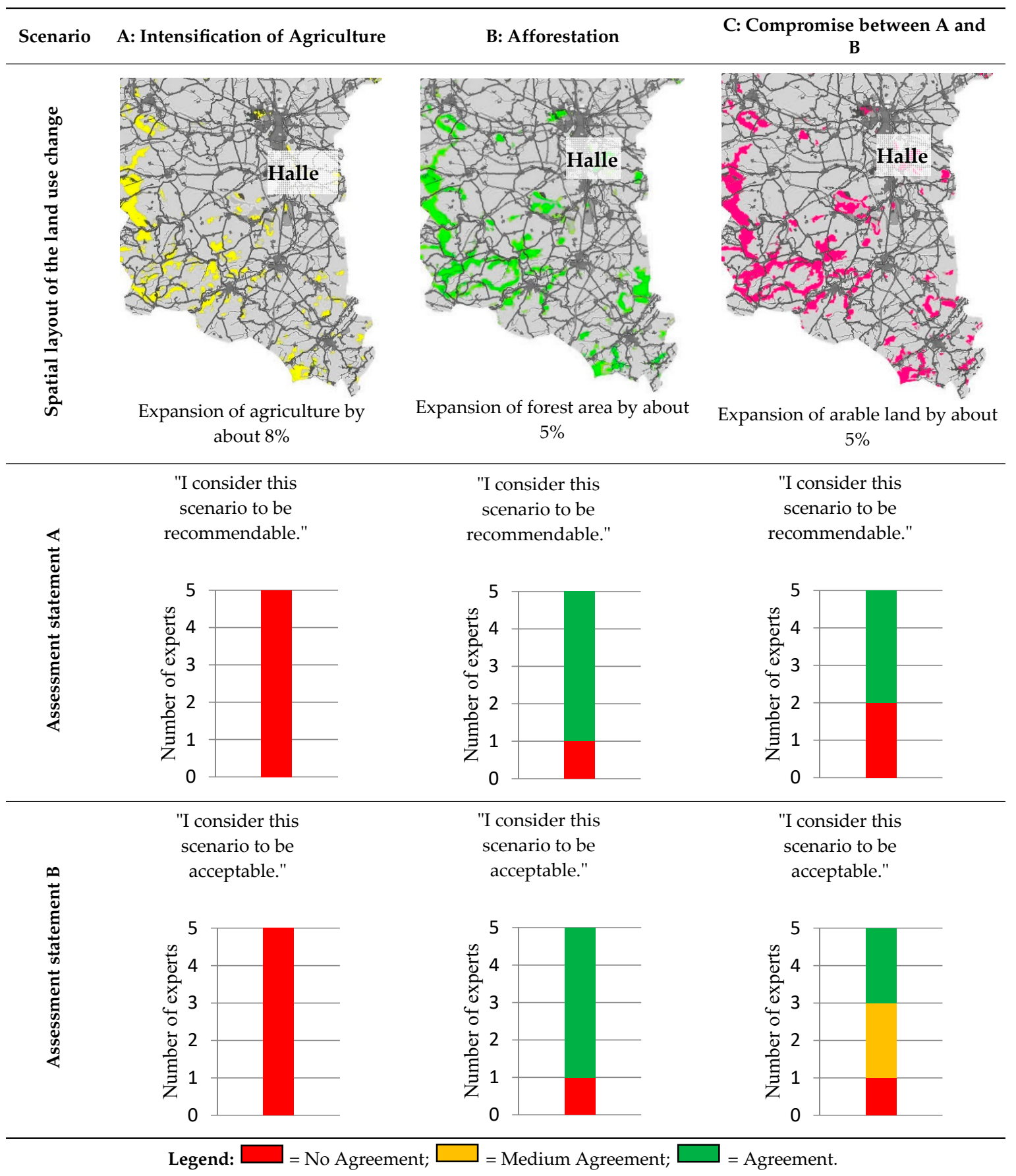

\section{Discussion}

Expert surveys in connection with the Delphi method, the confidence ratings and, based on this, the formation of qualitative confidence levels are suitable methods for qualifying expert knowledge and closing knowledge gaps, thus contributing to the operability of the ES concept for the planning on the regional level. The combination of methods reduces uncertainties in expert surveys due to the use of various measures. In Steps 1 and 2, a Delphi survey and a confidence rating were carried out. Moreover, in Step 2, confidence levels for the analysis of the results were formed. The consensus achieved in the Delphi survey can be viewed as an argument for its validity [25] and the confidence 
rating increases the level of confidence, since certainty in the assessments also increased in the context of rising consensus. The confidence levels identified uncertainties and confidence increased in the Delphi round of Step 2, which caused an increase in confidence in the results. In addition to the Delphi approach, the combination of a confidence rating with the assessment of ES provision potentials regarding confidence levels validated the results of the Delphi group from Step 2. Statements about future changes in the regional ES provision potential due to climate change were thereby made possible.

However, by combining various methods, inherent strengths and weaknesses in each individual method were also adopted [55]. In Table 7, the strengths and weaknesses in the individual methods as well as suggestions for improvement are displayed. For example, by including various expert groups, transdisciplinary studies were made possible. On the other hand, expertise is not completely verifiable. In addition, the confidence ratings might be biased by the assumption that experts have a high self-confidence which results in an overconfidence bias [56].

The number of experts in Steps 1 and 4 could be regarded as low, but, according to Eycott et al. (2011) [57], it is not unusual to have few experts participating in a Delphi survey. It was not possible to execute a Delphi round in Step 3 due to time limitations. The compromise scenario showed uncertainties in the assessment; a repeated survey could possibly have affected an increase in the robustness of the results; and a tendency towards more explicit rejection or agreement would presumably have been more pronounced.

Table 7. Strengths and weaknesses in the individual methods as well as suggestions for improvement. $\mathrm{ES}=$ Ecosystem services.

\begin{tabular}{|c|c|}
\hline Strengths & $\begin{array}{l}\text { - Transdisciplinary studies were made possible by surveys of two different types } \\
\text { of experts. } \\
\text { - } \quad \text { Experts are a suitable starting point for closing gaps in data [58]. } \\
\text { - Including stakeholders in the form of experts facilitates better acceptance and allows } \\
\text { further development and possible utilization of the courses of action. } \\
\text { - The Delphi approach increases the consensus and overcomes uncertainties [25]. } \\
\text { The Delphi approach activates latent pre-existing knowledge, regardless of degree of } \\
\text { competency in those surveyed [32]. }\end{array}$ \\
\hline Weaknesses & $\begin{array}{l}\text { - } \quad \text { Low number of experts in Steps } 1 \text { and } 4 . \\
\text { - } \quad \text { No Delphi survey in Step } 3 . \\
\text { - } \quad \text { Expertise not completely verifiable [59]. } \\
\text { - } \quad \text { Simplification of ecological processes for the assessment of ES provision potentials [60]. }\end{array}$ \\
\hline $\begin{array}{l}\text { Suggestions for } \\
\text { improvement }\end{array}$ & $\begin{array}{l}\text { - Surveys with other stakeholders such as farmers and citizens [61]. } \\
\text { - To increase the trust in the results, Delphi surveys in all steps are recommended. } \\
\text { - Combination of the Delphi method with in-depth interviews in order to better } \\
\text { - } \quad \text { Anderstand the context [62,63]. } \\
\text { hypotheses and development of the scenarios could generate application-oriented } \\
\text { output which would more likely be accepted [61]. } \\
\text { Development of differentiated scenarios through integration of adaptation measures } \\
\text { that go beyond changes in land cover (e.g., short-rotation plantations) [64]. } \\
\text { - More Delphi rounds until a pre-defined termination criterion is achieved (e.g., stability } \\
\text { in the answers [65] and a certain degree of agreement [33]). } \\
\text { - Selection of more ES in scenario modeling. }\end{array}$ \\
\hline
\end{tabular}

In this study, the confidence levels and ES provision potentials were high and very high for the current potential provision of cultural ES (recreation/landscape beauty and spiritual values), and food production. The cultural ES are being potentially provided by forest LCC. Food production is potentially supplied by agricultural LCC. In numerous studies, agricultural LCC currently display a high potential for food production (for example [64]). On the other hand, forest LCC frequently supply-in contrast to the results of this study - a variety of ES such as wood, water filtration and soil erosion control $[23,66,67]$. In our case, forest was regarded as providing regulating ES but the 
confidence levels were too low for further analysis. The connection between forest and cultural ES could be related to the historical development in Germany. Forests were excessively highlighted in the 19th century in German Romanticism poems, fairy tales and legends and remain to this day a symbol for wilderness and spirituality [68]. The forest is thus regarded as cultural heritage. The fact that forests are considered to be less relevant for provisioning ES such as timber and forest fruits could be due to the low share of forests in Saxony-Anhalt compared to other Federal States and the related low relevance for the GDP. The smaller LCC (e.g., forest-shrub-landscape) are regionally less relevant for potential provision of the ES. Smaller LCC can however be quite important for potential provision of special, regional-specific ES [25,69].

The regulating ES received in all survey groups predominantly low to medium ES provision potentials and confidence levels. Interestingly, local/regional and global climate regulation had no relevance for the region, which could be due to difficulties and uncertainties in the assessment of this type of ES. Literature reflects that confidence and consensus are lower when the basis for evidence is weak [70] or in the event that answers could possibly reduce a complex state of affairs [71]. However, Rodríguez et al. (2006) [11] noticed that regulating services are more likely to be taken for granted.

The confidence levels for the assessment under climate change show that, with a high level of confidence, the potential provision of food by agricultural LCC and the cultural ES from forest diminish. It is however noteworthy that the changes in the provision potentials occurring due to climate change are only marginal, and that they only appear in a few LCC. The provision potentials for agriculture and forest-related LCC decrease from a very high level to a high level. Possible reasons for this assessment could be that the experts do not consider noteworthy changes due to climate change in the region. Regions and sectors are impacted quite differently by the repercussions from climate change [7]. Nevertheless, this result is surprising since it would have been expected that the provision potential for food production is not at risk-rather, that it benefits to a greater extent from a longer vegetation period in connection with increased temperatures. On the other hand, the investigated region has already today a negative water balance [26]. The experts possibly assume that the trend of a negative water balance is increasing due to climate change and is becoming a disadvantage for food provision. A reason for the lower difference in the provision potential for cultural ES due to forest LCC could lie in the fact that forest will not suffer, even under climate change. In addition, Grêt-Regamey et al. (2013) [72] emphasized that, under climate change, forest displays, most of all, a high provision potential for cultural ES.

In the design of the scenarios, an ES trade-off was identified in the potential provision of food (agricultural LCC) and the potential provision of recreation/landscape beauty and spiritual values (forest LCC). Competition for land use is increasing due to climate change, despite the rather low impacts from climate change upon ES provision potentials in the region. All across Germany, a trade-off between forest and agriculture areas has been identified due to climate change, but in the provision of energy (energy wood vs. energy grains/corn) [73]. The scenarios facilitated a spatially explicit assessment based on acceptance levels for the courses of action for the ES provision potentials under climate change. The assessments of the scenarios made by the experts (type A) are linked with uncertainties, since the survey was not carried out as a Delphi method. The acceptance levels were highest for the afforestation scenario for improved provision of the cultural ES at the expense of the agricultural LCC, i.e., food provision. Retention of the spiritual values and recreation/landscape beauty seems to be regionally important according to the experts. This result is in agreement with the German Federal Nature Conservation Act which assures the recreational function of nature [51]. Since the experts linked recreation with forest, endorsement of the scenario of afforestation is understandable. The fact that the afforestation scenario was higher valued than agricultural intensification could be also related to the landscape in Saxony-Anhalt because it has a lower share of forest among the Federal States [42]. Therefore, forest might be seen as a precious asset, especially for people in Saxony-Anhalt with currently dominating intensive agriculture. This result shows the significance of cultural ES and how important it is to include them in an ES assessment. Regarding cultural ES, expert-based 
approaches are also advantageous, since cultural ES are difficult to ascertain quantitatively [11]. Moreover, the experts are most likely aware that afforestation is one of the most discussed measures for reducing the effects of climate change [12]. The huge role that forests play in local and global climate change and regulatory measures has already had an effect upon political decision making, e.g., REDD+ [74]. Respective guidelines are therefore targeted at an expansion of forested areas [67]. The low level of acceptance of the intensification scenario could also be founded in the knowledge related to climate-damaging repercussions of the intensification of agriculture [45].

\section{Conclusions}

We have presented an expert-based, transdisciplinary approach to the assessment of regional provision potential of ES based on climate change. In the process, we improved the matrix method by combining it with Delphi surveys, by surveying the experts with confidence ratings, and by forming standardized confidence levels to increase the level of confidence in the assessments. This methodological combination is well-suited for improving the reliability of an expert-based assessment approach. Furthermore, it is suitable for the ES assessment in regional planning. The most important ES were the provision of food, spiritual values and recreation/landscape beauty. Based on the matrix assessments, we generated scenarios for agricultural intensification, afforestation and a compromise for the two scenarios. We subsequently had these scenarios assessed by the experts to retain the acceptance level. In light of the hypotheses, it can be stated that the relevance of provisioning ES, reflected in food provision, was very high, but it was also found that cultural ES was important. Under climate change, the provision potentials of the ES in the region of Halle will change. The results of the matrix assessment show that the provision potential of the selected ES will certainly decrease due to climate change. The hypothesis was substantiated that agricultural intensification was accepted less than afforestation, which could indicate that forest carries high cultural value, but is also a climate-promoting measure.

Author Contributions: This work originated at the Department of Sustainable Landscape Development at Martin-Luther University Halle-Wittenberg. L.G. and C.F. conceived and designed the study. L.G. selected the experts, conducted the survey, analyzed the data and performed the literature review. L.G. and J.K. developed and wrote the paper. C.F. reviewed the paper.

Funding: We acknowledge the financial support by the Martin-Luther-University Halle-Wittenberg within the funding program for Open Access Publishing by the German Research Foundation (DFG).

Acknowledgments: The authors gratefully acknowledge the participants of the surveys. Furthermore, we would like to thank Paul Ronning for the professional English proofread of the paper.

Conflicts of Interest: The authors declare no conflict of interest.

\section{Appendix A}

Table A1. Assessment for food production, recreation/landscape beauty and spiritual values of the first group of expert type B (="group 1") that was asked to fill out the matrix in Step 2. ES = Ecosystem service.

\begin{tabular}{|c|c|c|c|c|c|}
\hline ES & $\begin{array}{l}\text { Land Cover } \\
\text { Class }\end{array}$ & $\begin{array}{l}\text { Land Cover } \\
\text { Subclass }\end{array}$ & $\begin{array}{c}\text { Current Provision } \\
\text { Potential of ES } \\
\text { Color }=\text { Confidence } \\
\text { Level, } \\
\text { Value }=\text { Mean }\end{array}$ & $\begin{array}{c}\text { Future Provision } \\
\text { Potential of ES } \\
\text { Color = Confidence } \\
\text { Level, } \\
\text { Value }=\text { Mean }\end{array}$ & $\begin{array}{c}\text { Changes in ES } \\
\text { Provision by } \\
\text { Climate } \\
\text { Change }\end{array}$ \\
\hline \multirow{7}{*}{$\begin{array}{c}\text { Food } \\
\text { provision }\end{array}$} & \multirow{3}{*}{ Forest area } & Mixed forest & 1.33 & 1.75 & - \\
\hline & & Coniferous forest & 1.08 & 1.25 & - \\
\hline & & Broad-leaved forest & 1.5 & 2.08 & - \\
\hline & \multirow{4}{*}{$\begin{array}{l}\text { Semi-natural and } \\
\text { agricultural area }\end{array}$} & Agriculture & 4.75 & 4.33 & $\rightarrow$ \\
\hline & & $\begin{array}{l}\text { Fruit trees and } \\
\text { berries }\end{array}$ & 4.33 & 3.5 & - \\
\hline & & Vineyards & 3.67 & 3.08 & $\searrow$ \\
\hline & & Arable land & 4.67 & 4.25 & $\rightarrow$ \\
\hline
\end{tabular}


Table A1. Cont.

\begin{tabular}{|c|c|c|c|c|c|}
\hline ES & $\begin{array}{l}\text { Land Cover } \\
\text { Class }\end{array}$ & $\begin{array}{l}\text { Land Cover } \\
\text { Subclass }\end{array}$ & $\begin{array}{c}\text { Current Provision } \\
\text { Potential of ES } \\
\text { Color = Confidence } \\
\text { Level, } \\
\text { Value }=\text { Mean }\end{array}$ & $\begin{array}{c}\text { Future Provision } \\
\text { Potential of ES } \\
\text { Color = Confidence } \\
\text { Level, } \\
\text { Value }=\text { Mean }\end{array}$ & $\begin{array}{c}\text { Changes in ES } \\
\text { Provision by } \\
\text { Climate } \\
\text { Change }\end{array}$ \\
\hline \multirow{5}{*}{$\begin{array}{l}\text { Spiritual } \\
\text { values }\end{array}$} & \multirow[b]{2}{*}{ Forest area } & Mixed forest & 3.75 & 3.92 & - \\
\hline & & Coniferous forest & 3.5 & 3.67 & - \\
\hline & \multirow[t]{3}{*}{$\begin{array}{l}\text { Semi-natural and } \\
\text { agricultural area }\end{array}$} & $\begin{array}{l}\text { Fruit trees and } \\
\text { berries }\end{array}$ & 2.08 & 2.5 & - \\
\hline & & Vineyards & 2.17 & 2.67 & - \\
\hline & & Arable land & 1 & 1.17 & - \\
\hline \multirow{4}{*}{$\begin{array}{l}\text { Recreation/ } \\
\text { landscape } \\
\text { beauty }\end{array}$} & Forest area & Mixed forest & 4.33 & 3.92 & $\rightarrow$ \\
\hline & \multirow[t]{3}{*}{$\begin{array}{l}\text { Semi-natural and } \\
\text { agricultural area }\end{array}$} & $\begin{array}{l}\text { Fruit trees and } \\
\text { berries }\end{array}$ & 3.08 & 2.92 & - \\
\hline & & Vineyards & 2.83 & 2.92 & - \\
\hline & & Arable land & 1.42 & 2 & - \\
\hline
\end{tabular}

Legend: $\square$ = Very high confidence level; $\square$ = High confidence level; $\square$ = Medium confidence level; $\square$ = Low confidence leve; $\square$ = Very low confidence level; $\searrow$ = Under climate change influences, the potential provision of this ES decreases (by at least 0.5 ) $\rightarrow \rightarrow=$ Under climate change influences, the potential provision of this ESS does not change; $\nearrow=$ Under climate change influences, the potential provision of this ES increases (by at least 0.5 ); - = This ES does not fulfill the prerequisites for an analysis of the assessment under climate change (see Section 2.5.2).

\section{References}

1. Millennium Ecosystem Assessment (MEA) (Ed.) Ecosystems and Human Well-Being: Synthesis; Island Press: Washington, DC, USA, 2005.

2. Mooney, H.; Larigauderie, A.; Cesario, M.; Elmquist, T.; Hoegh-Guldberg, O.; Lavorel, S.; Mace, G.M.; Palmer, M.; Scholes, R.; Yahara, T. Biodiversity, climate change, and ecosystem services. Curr. Opin. Environ. Sustain. 2009, 1, 46-54. [CrossRef]

3. Schröter, D.; Cramer, W.; Leemans, R.; Prentice, I.C.; Araújo, M.B.; Arnell, N.W.; Bondeau, A.; Bugmann, H.; Carter, T.R.; Gracia, C.A.; et al. Ecosystem service supply and vulnerability to global change in Europe. Science 2005, 310, 1333-1337. [CrossRef] [PubMed]

4. Daily, G. (Ed.) Nature's Services: Societal Dependence on Natural Ecosystems; Island Press: Washington, DC, USA, 1997.

5. Raudsepp-Hearne, C.; Peterson, G.D.; Tengö, M.; Bennett, E.M.; Holland, T.; Benessaiah, K.; MacDonald, G.K.; Pfeifer, L. Untangling the Environmentalist's Paradox: Why Is Human Well-being Increasing as Ecosystem Services Degrade? BioScience 2010, 60, 576-589. [CrossRef]

6. The Economics of Ecosystems and Biodiversity (TEEB). The Economics of Ecosystems and Biodiversity: Mainstreaming the Economics of Nature: A Synthesis of the Approach, Conclusions and Recommendations of TEEB; TEEB: Geneva, Switzerland, 2010.

7. The Intergovernmental Panel on Climate Change (IPCC). Climate Change 2014: Synthesis Report. Contribution of Working Groups I, II and III to the Fifth Assessment Report of the Contribution of Working Groups I, II and III to the Fifth Assessment Report of the Contribution of Working Groups I, II and III to the Fifth Assessment Report of the Intergovernmental Panel on Climate Change; IPCC: Geneva, Switzerland, 2014.

8. Haines-Young, R.; Potschin, M. Common International Classification of Ecosystem Services (CICES): Consultation on Version 4, August-December 2012; European Environment Agency: Copenhagen, Denmark, 2013.

9. Maynard, S.; James, D.; Davidson, A. The development of an Ecosystem Services Framework for South East Queensland. Environ. Manag. 2010, 45, 881-895. [CrossRef] [PubMed]

10. Intergovernmental Panel on Climate Change (IPCC). Change 2001: Impacts, Adaptation, and Vulnerability. Contribution of Working Group II to the Third Assessment Report of the Intergovernmental Panel on Climate Change; Cambridge University Press: Cambridge, UK, 2001. 
11. Rodríguez, J.P.; Beard, D.T., Jr.; Bennett, E.M.; Cumming, G.S.; Cork, S.J.; Agard, J.; Dobson, A.P.; Peterson, G.D. Trade-offs across Space, Time, and Ecosystem Services. Ecol. Soc. 2006, 11, 28. [CrossRef]

12. Fürst, C.; Volk, M.; Pietzsch, K.; Makeschin, F. Pimp your landscape: A tool for qualitative evaluation of the effects of regional planning measures on ecosystem services. Environ. Manag. 2010, 46, 953-968. [CrossRef] [PubMed]

13. Hagemeier-Klose, M.; Albers, M.; Richter, M.; Deppisch, S. Szenario-Planung als Instrument einer „klimawandelangepassten“ Stadt- und Regionalplanung-Bausteine der zukünftigen Flächenentwicklung und Szenarienkonstruktion im Stadt-Umland-Raum Rostock. Raumforsch. Raumordn. 2013, 71, 413-426. [CrossRef]

14. Koo, H.; Kleemann, J.; Fürst, C. Land Use Scenario Modeling Based on Local Knowledge for the Provision of Ecosystem Services in Northern Ghana. Land 2018, 7, 59. [CrossRef]

15. Seppelt, R.; Lautenbach, S.; Volk, M. Identifying trade-offs between ecosystem services, land use, and biodiversity: A plea for combining scenario analysis and optimization on different spatial scales. Curr. Opin. Environ. Sustain. 2013, 5, 458-463. [CrossRef]

16. Peterson, G.D.; Cumming, G.S.; Carpenter, S.R. Scenario Planning: A Tool for Conservation in an Uncertain World. Conserv. Biol. 2003, 17, 358-366. [CrossRef]

17. Grêt-Regamey, A.; Sirén, E.; Brunner, S.H.; Weibel, B. Review of decision support tools to operationalize the ecosystem services concept. Ecosyst. Serv. 2017, 26, 306-315. [CrossRef]

18. Hulse, D.; Eilers, J.; Freemark, K.; Hummon, C.; White, D. Planning Alternative Future Landscapes in Oregon: Evaluating Effects on Water Quality and Biodiversity. Landsc. J. 2000, 19, 1-19. [CrossRef]

19. Kleemann, J.; Celio, E.; Nyarko, B.K.; Jimenez-Martinez, M.; Fürst, C. Assessing the risk of seasonal food insecurity with an expert-based Bayesian Belief Network approach in northern Ghana, West Africa. Ecol. Complex. 2017, 32, 53-73. [CrossRef]

20. Burkhard, B.; Kroll, F.; Nedkov, S.; Müller, F. Mapping ecosystem service supply, demand and budgets. Ecol. Indic. 2012, 21, 17-29. [CrossRef]

21. Koschke, L.; Fürst, C.; Frank, S.; Makeschin, F. A multi-criteria approach for an integrated land-cover-based assessment of ecosystem services provision to support landscape planning. Ecol. Indic. 2012, 21, 54-66. [CrossRef]

22. Hou, Y.; Burkhard, B.; Müller, F. Uncertainties in landscape analysis and ecosystem service assessment. J. Environ. Manag. 2013, 127, 117-131. [CrossRef] [PubMed]

23. Burkhard, B.; Kroll, F.; Müller, F.; Windhorst, W. Landscapes' capacities to provide ecosystem services-A concept for land-cover based assessments. Landsc. Online 2009, 15, 1-22. [CrossRef]

24. Kaiser, G.; Burkhard, B.; Römer, H.; Sangkaew, S.; Graterol, R.; Haitook, T.; Sterr, H.; Sakuna-Schwartz, D. Mapping tsunami impacts on land cover and related ecosystem service supply in Phang Nga, Thailand. Nat. Hazards Earth Syst. Sci. 2013, 13, 3095-3111. [CrossRef]

25. Jacobs, S.; Burkhard, B.; Van Daele, T.; Staes, J.; Schneiders, A. 'The Matrix Reloaded': A review of expert knowledge use for mapping ecosystem services. Ecol. Model. 2015, 295, 21-30. [CrossRef]

26. Landesamtes für Umweltschutz Sachsen-Anhalt. Durchführung einer Untersuchung zu den Folgen des Klimawandels in Sachsen-Anhalt. Los 4: Anpassungsmaßnahmen. Kurzfassung Projektbericht November 2012; Landesamtes für Umweltschutz Sachsen-Anhalt: Halle, Germany, 2012.

27. Foley, J.A.; Defries, R.; Asner, G.P.; Barford, C.; Bonan, G.; Carpenter, S.R.; Chapin, F.S.; Coe, M.T.; Daily, G.C.; Gibbs, H.K.; et al. Global consequences of land use. Science 2005, 309, 570-574. [CrossRef] [PubMed]

28. Van Jaarsveld, A.S.; Biggs, R.; Scholes, R.J.; Bohensky, E.; Reyers, B.; Lynam, T.; Musvoto, C.; Fabricius, C. Measuring conditions and trends in ecosystem services at multiple scales: The Southern African Millennium Ecosystem Assessment (SAfMA) experience. Philos. Trans. R. Soc. Lond. Ser. B Biol. Sci. 2005, 360, 425-441. [CrossRef] [PubMed]

29. Haines-Young, R.; Potschin, M.; Kienast, F. Indicators of ecosystem service potential at European scales: Mapping marginal changes and trade-offs. Ecol. Indic. 2012, 21, 39-53. [CrossRef]

30. Seppelt, R.; Dormann, C.F.; Eppink, F.V.; Lautenbach, S.; Schmidt, S. A quantitative review of ecosystem service studies: Approaches, shortcomings and the road ahead. J. Appl. Ecol. 2011, 48, 630-636. [CrossRef]

31. Grêt-Regamey, A.; Bebi, P.; Bishop, I.D.; Schmid, W.A. Linking GIS-based models to value ecosystem services in an Alpine region. J. Environ. Manag. 2008, 89, 197-208. [CrossRef] [PubMed] 
32. Häder, M. Delphi-Befragungen: Ein Arbeitsbuch, 2nd ed.; VS Verlag für Sozialwissenschaften: Wiesbaden, Germany, 2009.

33. Linstone, H.A.; Turoff, M. The Delphi Method. Techniques and Applications; Addison-Wesley: Reading, MA, USA, 1975.

34. Landeta, J.; Barrutia, J.; Lertxundi, A. Hybrid Delphi: A methodology to facilitate contribution from experts in professional contexts. Technol. Forecast. Soc. Chang. 2011, 78, 1629-1641. [CrossRef]

35. Crossman, N.D.; Burkhard, B.; Nedkov, S.; Willemen, L.; Petz, K.; Palomo, I.; Drakou, E.G.; Martín-Lopez, B.; McPhearson, T.; Boyanova, K.; et al. A blueprint for mapping and modelling ecosystem services. Ecosyst. Serv. 2013, 4, 4-14. [CrossRef]

36. Intergovernmental Panel on Climate Change (IPCC). Confidence and Likelihood in the IPCC Fifth Assessment Report; IPCC: Geneva, Switzerland, 2013. Available online: http://www.environment.gov.au/climatechange/publications / fact-sheet-confidence-likelihood (accessed on 13 March 2018).

37. Mastrandrea, M.D.; Mach, K.J.; Plattner, G.-K.; Edenhofer, O.; Stocker, T.F.; Field, C.B.; Ebi, K.L.; Matschoss, P.R. The IPCC AR5 guidance note on consistent treatment of uncertainties: A common approach across the working groups. Clim. Chang. 2011, 108, 675-691. [CrossRef]

38. Frank, S.; Fürst, C.; Witt, A.; Koschke, L.; Makeschin, F. Making use of the ecosystem services concept in regional planning-Trade-offs from reducing water erosion. Landsc. Ecol. 2014, 29, 1377-1391. [CrossRef]

39. Regionale Planungsgemeinschaft Halle (RPGH). Regionaler Entwicklungsplan für die Planungsregion Halle; RPGH: Halle, Germany, 2010.

40. European Environmental Agency (EEA). CLC-2006 Technical Guidelines; EEA: Copenhagen, Denmark, 2007.

41. PiSolution. GISCAME; PiSolution: Markkleeberg, Germany, 2018.

42. Bundesministerium für Ernährung und Landwirtschaft (BMEL). Ergebnisse der Bundeswaldinventur 2012; BMEL: Bonn/Berlin, Germany, 2016; Available online: https:/ / www.bundeswaldinventur.de/fileadmin/ SITE_MASTER/content/Dokumente/Downloads/BMEL_BWI_Bericht_Ergebnisse_2012_RZ02_web.pdf (accessed on 5 April 2018).

43. Hemmerling, U.; Pascher, P.; Nass, S.; Seidel, C. Informationen zur Deutschen Landwirtschaft. Zahlen, Daten, Fakten. 2013. Available online: https://information-medien-agrar.de/webshop/mediafiles/PDF / 104-117_info-landwirtschaft.pdf (accessed on 5 April 2018).

44. GeoBasis-DE; Bundesamt für Kartographie und Geodäsie (BKG): Frankfurt am Main, Germany, 2018.

45. Intergovernmental Panel on Climate Change (IPCC). Climate Change 2007: Synthesis Report. Contribution of Working Groups I, II and III to the Fourth Assessment. Report of the Intergovernmental Panel on Climate Change; IPCC: Geneva, Switzerland, 2007.

46. Curtis, I.A. Valuing ecosystem goods and services: A new approach using a surrogate market and the combination of a multiple criteria analysis and a Delphi panel to assign weights to the attributes. Ecol. Econ. 2004, 50, 163-194. [CrossRef]

47. Porst, R. Fragebogen. Ein Arbeitsbuch, 4th ed.; Springer: Wiesbaden, Germany, 2014.

48. Curzon, H.F.; Kontoleon, A. From ignorance to evidence? The use of programme evaluation in conservation: Evidence from a Delphi survey of conservation experts. J. Environ. Manag. 2016, 180, 466-475. [CrossRef] [PubMed]

49. Kulczyk, S.; Woźniak, E.; Kowalczyk, M.; Derek, M. Ecosystem Services in tourism and recreation: Revisiting the Classification Problem. Econ. Environ. 2014, 51, 84-92.

50. Fürst, C.; König, H.; Pietzsch, K.; Ende, H.; Makeschin, F. Pimp your landscape-A generic approach integrating regional stakeholder needs into land use planning. Ecol. Soc. 2010, 15, 34. [CrossRef]

51. Bundesnaturschutzgesetz. Bundesministerium der Justiz und für Verbraucherschutz; BNatSchG: Berlin, Germany, 2009.

52. Kok, K.; van Vliet, M.; Bärlund, I.; Dubel, A.; Sendzimir, J. Combining participative backcasting and exploratory scenario development: Experiences from the SCENES project. Technol. Forecast. Soc. Chang. 2011, 78, 835-851. [CrossRef]

53. Palomo, I.; Martín-López, B.; López-Santiago, C.; Montes, C. Participatory scenario planning for protected areas management under the ecosystem services framework: The Doñana social-ecological system in southwestern Spain. Ecol. Soc. 2011, 16, 23. [CrossRef] 
54. Gesetz zur Erhaltung und Bewirtschaftung des Waldes, zur Förderung der Forstwirtschaft Sowie zum Betreten und Nutzen der Freien Landschaft im Land Sachsen-Anhalt. Landeswaldgesetz Sachsen-AnhaltLWaldG; Ministerium für Justiz und Gleichstellung des Landes Sachsen-Anhalt: Magdeburg, Germany, 2016.

55. Amaratunga, D.; Baldry, D.; Sarshar, M.; Newton, R. Quantitative and qualitative research in the built environment: Application of "mixed" research approach. Work Study 2002, 51, 17-31. [CrossRef]

56. Bolger, F.; Wright, G. Improving the Delphi process: Lessons from social psychological research. Technol. Forecast. Soc. Chang. 2011, 78, 1500-1513. [CrossRef]

57. Eycott, A.E.; Marzano, M.; Watts, K. Filling evidence gaps with expert opinion: The use of Delphi analysis in least-cost modelling of functional connectivity. Landsc. Urban Plan. 2011, 103, 400-409. [CrossRef]

58. Sutherland, W.J. Predicting the ecological consequences of environmental change: A review of the methods. J. Appl. Ecol. 2006, 43, 599-616. [CrossRef]

59. Hasson, F.; Keeney, S. Enhancing rigour in the Delphi technique research. Technol. Forecast. Soc. Chang. 2011, 78, 1695-1704. [CrossRef]

60. Scolozzi, R.; Morri, E.; Santolini, R. Delphi-based change assessment in ecosystem service values to support strategic spatial planning in Italian landscapes. Ecol. Indic. 2012, 21, 134-144. [CrossRef]

61. MacMillan, D.C.; Marshall, K. The Delphi process?: An expert-based approach to ecological modelling in data-poor environments. Anim. Conserv. 2006, 9, 11-19. [CrossRef]

62. Kaplowitz, M.D.; Hoehn, J.P. Do focus groups and individual interviews reveal the same information for natural resource valuation? Ecol. Econ. 2001, 36, 237-247. [CrossRef]

63. Kleemann, J.; Baysal, G.; Bulley, H.N.N.; Fürst, C. Assessing driving forces of land use and land cover change by a mixed-method approach in north-eastern Ghana, West Africa. J. Environ. Manag. 2017, 196, 411-442. [CrossRef] [PubMed]

64. Fürst, C.; Frank, S.; Witt, A.; Koschke, L.; Makeschin, F. Assessment of the effects of forest land use strategies on the provision of ecosystem services at regional scale. J. Environ. Manag. 2013, 127, 96-116. [CrossRef] [PubMed]

65. Dajani, J.S.; Sincoff, M.Z.; Talley, W.K. Stability and agreement criteria for the termination of Delphi studies. Technol. Forecast. Soc. Chang. 1979, 13, 83-90. [CrossRef]

66. Sohel, M.S.I.; Ahmed Mukul, S.; Burkhard, B. Landscape's capacities to supply ecosystem services in Bangladesh: A mapping assessment for Lawachara National Park. Ecosyst. Serv. 2015, 12, 128-135. [CrossRef]

67. Witt, A.; Fürst, C.; Frank, S.; Koschke, L.; Makeschin, F. Regionalisation of climate change sensitive forest development types for potential afforestation areas. J. Environ. Manag. 2013, 127, 48-55. [CrossRef] [PubMed]

68. Jung-Kaiser, U. (Ed.) Der Wald als Romantischer Topos; Peter Lang: Frankfurt am Main, Germany, 2007.

69. Vihervaara, P.; Kumpula, T.; Tanskanen, A.; Burkhard, B. Ecosystem services-A tool for sustainable management of human-environment systems. Case study Finnish Forest Lapland. Ecol. Complex. 2010, 7 , 410-420. [CrossRef]

70. Moreno, V.; Morales, M.B.; Traba, J. Avoiding over-implementation of agri-environmental schemes for steppe bird conservation: A species-focused proposal based on expert criteria. J. Environ. Manag. 2010, 91, 1802-1809. [CrossRef] [PubMed]

71. Martin, T.G.; Kuhnert, P.M.; Mengersen, K.; Possingham, H.P. The Power of expert opinion in ecological models using bayesian methods: Impact of grazing on birds. Ecol. Appl. 2005, 15, 266-280. [CrossRef]

72. Grêt-Regamey, A.; Brunner, S.H.; Altwegg, J.; Christen, M.; Bebi, P. Integrating Expert Knowledge into Mapping Ecosystem Services Trade-offs for Sustainable Forest Management. Ecol. Soc. 2013, 18. [CrossRef]

73. Steinhäußer, R.; Siebert, R.; Steinführer, A.; Hellmich, M. National and regional land-use conflicts in Germany from the perspective of stakeholders. Land Use Policy 2015, 49, 183-194. [CrossRef]

74. United Nations Framework Convention on Climate Change (UNFCCC). Factsheet REDD+. Available online: http:/ / redd.unfccc.int/fact-sheets.html (accessed on 31 March 2018).

(C) 2018 by the authors. Licensee MDPI, Basel, Switzerland. This article is an open access article distributed under the terms and conditions of the Creative Commons Attribution (CC BY) license (http://creativecommons.org/licenses/by/4.0/). 